\title{
Influence of Gamma Irradiation and Seed Treatment Chemicals on Seed Longevity of Bengal Gram (Cicer arietinum L.) and Black Gram (Vigna mungo L.)
}

\author{
$\operatorname{Pranesh}^{1}$, S.R. Doddagoudar*1, S.N. Vasudevan", \\ N.M. Shakunthala ${ }^{1}$ andD.S. Aswathanarayana ${ }^{2}$ \\ ${ }^{1}$ Department of Seed Science and Technology, ${ }^{2}$ Department of Plant Pathology, \\ University of Agricultural Sciences, Raichur, Karnataka-584 104, India \\ *Corresponding author
}

\section{Keywords}

Bengal gram, Black gram, Gamma irradiation, Seed treatment chemicals, Seed germination, Abnormal seedlings, Vigour

Article Info

Accepted:

26 December 2018

Available Online:

10 January 2019

\section{A B S T R A C T}

A laboratory experiment was conducted in the Department of Seed Science and Technology, College of Agriculture, UAS, Raichur to study the influence of gamma irradiation and seed treatment chemicals on seed longevity of bengal gram (Cicer arietinum L.) and black gram (Vigna mungo L.). The experiment consisted of nine treatments with different dosage of gamma irradiation and seed treatment chemicals. Among the different treatments imposed, significantly higher seed germination (87.0 and $83.8 \%$ ), germination rate index (4684 and 3946), peak value of germination (23.5 and 20.0), seedling vigour index (2069 and 1755), dehydrogenase enzyme activity (1.816 and $1.576 \mathrm{OD}$ value) and alpha amylase enzyme activity $(23.5$ and $18.8 \mathrm{~mm})$ with lowest abnormal seedling $(8.3$ and $9.0 \%)$ and mean germination time (2.10 and 2.34$)$ were recorded even after nine months storage, respectively in bengal gram and black gram, respectively by treating the seeds with the combination of malathion + thiram each @ 2.0 $\mathrm{g} / \mathrm{kg}$ of seed as compared to all other treatments and control. The above treatment was also effective in control of cent per cent insect eggs there by without any seed damage and consequently no weight loss compared to control with $23.00,12.92$ and 7.76 per cent insect egg, seed damage and weight loss, respectively in bengal gram. But in case of black gram the seed infestation did not take place in any of the treatments including control. Further, exposing the seeds to the gamma irradiation $\left(T_{2}\right.$ to $\left.T_{6}\right)$ showed a significant reduction in all above seed quality parameters with an increase in gamma irradiation dosage. While, the seed quality parameters such as, abnormal seedlings, dead seeds, mean germination time and electrical conductivity increased with the increase in dosage of gamma irradiation. However, among all the gamma irradiation treatments imposed, the highest dosage of gamma irradiation (T6-100 Gy) recorded the least seed damage (1.46\%) and weight loss $(0.02 \%)$ only. 


\section{Introduction}

Pulses are an integral part of an average Indian meal as a main source of protein wherein, a large proportion of population is vegetarian. Among the pulses, chickpea (Cicer arietinum L.) is popularly cultivated in sub tropical and semi arid to warm temperature region under receding soil moisture. It is one of the earliest food legumes cultivated by man which plays an important role in human diet. India is the third largest producer of chickpea accounting for 68 per cent of worlds production with a cultivated area of 8.39 mha and production of $7.05 \mathrm{mt}$, with an average productivity of 840 $\mathrm{kg}$ per ha (Anonymous, 2016). Another important pulse crop, black gram (Vigna mungo L.) or urd is reported to be originated from India which also happens to be the largest producer and consumer of black gram in the world. In India, black gram contributes about 13 per cent of total pulse area and 10 per cent of total production covering an area of 3.62 mha with a production of $1.94 \mathrm{mt}$ and a productivity of $537 \mathrm{~kg}$ per ha (Anonymous, 2016).

Among the various pests of pulses, the pulse beetle is a major pest since they infest the grains or seeds both in field as well as store houses where they multiply rapidly and cause heavy losses (Aslam, 2004). Considering the extent of losses and damage to pulse produce, several research strategies are being adopted for management of these stored pests and disease of which, use of fungicides, insecticides, fumigants and ionizing radiations provide protection to the seeds. Seed treatment with fungicides is known to improve the germination of seeds by protecting the seeds and young seedlings from many seed borne and soil borne pathogens (Taylor et al., 1998). Among the fungicides, thiram acts as a protective agent against seed deterioration by prevention of fungal invasion and physiological ageing as a result of which the seed viability can be maintained for comparatively longer period of time (Savitri et al., 1998).

Ionizing radiations such as ultraviolet rays, $\mathrm{X}$ rays and gamma rays has the potential to protect seeds from insect infestation and microbial contamination through sterilization. However, in recent years gamma radiation has become the most potent and viable solution for control of these insects with high efficiency and with little side effects. This process consists of disinfecting the seeds with a determined dose of radiation which inhibits the reproduction and even causes complete death of the infesting insects (Richard and Patrick, 2014). These gamma rays are the physical mutagens which are non-particulate ionizing radiations, having high energy and penetrable capacity in biological tissues and make changes in base, disruption of hydrogen bonds between complementary stands of DNA (Borzouei et al., 2010).

Gamma radiation can be used for alteration of physiological characters (Kiong et al., 2008). The biological effect of gamma-rays is based on the interaction with atoms or molecules in the cell, particularly water, to produce free radicals (Kovacs and Keresztes, 2002). These radicals can damage or modify important components of plant cells and have been reported to affect the morphology, anatomy, biochemistry and physiology of plants depending on the radiation dose (Ashraf et al., 2003). The effects include changes in the plant cellular structure and metabolism e.g., dilation of thylakoid membranes, alteration in photosynthesis, modulation of anti-oxidative system and accumulation of phenolic compounds (Kovacs and Keresztes, 2002; Kim et al., 2004; and Ashraf, 2009). Further, several workers have also reported the stimulatory effect of these gamma irradiation on plant growth at low dosage (Woodstock and Justice, 1967). While, irradiation of seeds 
at higher doses disturbs the synthesis of protein (Xiuzher, 1994), hormone balance (Rabie et al., 1996), leaf gas exchange (Stoeva and Bineva, 2001), water exchange and enzyme activity (Stoeva et al., 2001). These morphological, structural and functional changes depend on the strength and duration of gamma-irradiation stress and also the crop species on which the treatments are imposed.

Looking into wide applicability of gamma irradiation and also the dose sensitivity for a particular crop and its application, in the days to come this technology may be used for stored pest management in the seed storage godown. But what is its effect (negative or positive) on seed quality parameters need to be assessed particularly with respect to the pulses which are more sensitive to the gamma rays. Keeping in view the above facts, the present investigation was carried out with an objective to study the "Influence of gamma irradiation and seed treatment chemicals on seed longevity of bengal gram (Cicer arietinum L.) and black gram (Vigna mungo L.)".

\section{Materials and Methods}

An experiment was conducted in the Department of Seed Science and Technology, College of Agriculture, University of Agricultural Sciences, Raichur during the year 2015-16 to study the Influence of gamma irradiation and seed treatment chemicals on seed longevity of bengal gram (Cicer arietinum L.) and black gram (Vigna mungo L.)". The experiment consisted of nine treatments. Viz., $\mathrm{T}_{1}$ : Control, five dosages of gamma irradiation $\left(\mathrm{T}_{2}\right.$ to $\left.\mathrm{T}_{6}\right) \mathrm{T}_{2}: 200 \mathrm{~Gy}, \mathrm{~T}_{3}$ : $400 \mathrm{~Gy}, \mathrm{~T}_{4}: 600 \mathrm{~Gy}, \mathrm{~T}_{5}: 800 \mathrm{~Gy}, \mathrm{~T}_{6}: 1000 \mathrm{~Gy}$, three seed treatment chemicals, $\mathrm{T}_{7}$ : Melathion at $2 \mathrm{~g}$ per $\mathrm{kg}$ of seed, $\mathrm{T}_{8}$ : Thiram at $2 \mathrm{~g}$ per $\mathrm{kg}$ of seed and $\mathrm{T}_{9}$ : Melathion + Thiram each at 2 $\mathrm{g}$ per $\mathrm{kg}$ of seed. The experiment was conducted in a completely randomized design in four replications. For imposition of gamma irradiation treatments, $3 \mathrm{~kg}$ seed was used for each treatment. Since, the capacity of sample chamber was only $1.5 \mathrm{~kg}$, the seed was divided into two parts and exposed twice. Once after filling the seeds in the container the lid was closed.

Then the required gamma irradiation was set as per the treatments. Later the sample chamber (vertical drawer) moves inside cobalt-60 radiation isotope which emits gamma irradiation. The duration taken for gamma irradiation will be automatically adjusted as per the dose set.

While, for imposition of seed treatment chemicals, thiram (fungicide) and malathion (insecticide), the seeds were placed in a plastic tray and the required quantity of thiram, malathion and their combinations were dusted after sprinkling a little quantity water to the seeds and mixed thoroughly in order to have uniform seed coating. The seeds after treatment imposition were stored in cloth bag for nine months at room temperature. The monthly and bimonthly observations on various parameters were recorded and the mean value of crops presented in table 1 and 2.

The germination (germn) test was conducted in four replicates of 100 seeds each following between paper method in walk-in a seed germinator maintained at $25 \pm 2{ }^{\circ} \mathrm{C}$ temperature and 90 per cent $\mathrm{RH}$ for 8 days (ISTA, 2013). Similarly, the abnormal seedlings (Ab S) and dead seeds (DS) were recorded as per ISTA (ISTA, 2013). While, the mean germination time (MGT) was computed by adopting the formula suggested by (Azimi et al., 2013). Whereas, the germination rate index (GRI) was determined as per the procedure prescribed by Mudaris (1998), peak value of germination (PVG) by (Gairola et al., 2011), shoot length (SL), root 
length (RL), seedling dry weight (SDW), seedling vigour index (SVI) by Abdul-Baki and Anderson (1973), insect egg and seed damage by (Tamiru et al., 2016), percent weight loss by Harris and Lindblad (1978), dehydrogenase enzyme acticity (DH) by Kittock and Law (1968),, alpha amylase enzyme activity by Simpson and Naylor (1962) and electrical conductivity (EC) by (Milosevic et al., 2010) were recorded. The experimental data thus obtained were statically analysed by the procedure prescribed by (Sundararaj et al., 1972).

\section{Results and Discussion}

Among the different treatments imposed, significantly higher seed germination (93.5 and $91.0 \%$ ) was recorded by $\mathrm{T}_{9}$ (combination of melathion and thiram each @ $2 \mathrm{~g} / \mathrm{kg}$ of seed) compared to all other treatments and control (90.5 and $85.3 \%)$ in bengal gram and black gram at initial months after storage, respectively (Table 1a and 2a). While, the seed germination decreased (87.0 and $83.8 \%$ ) in $\mathrm{T}_{9}$ after nine months after storage period in bengal gram and black gram, respectively. This may be due to better protection of seeds by both the combination of insecticide (melathion) and fungicide (thiram) when used at optimum dose. These results are in line with the earlier findings of Ravikumar et al., (1987) who reported that soybean seeds treated with melathion $(2 \mathrm{~g} / \mathrm{kg}$ of seed) or in combination with fungicide (thiram @ $2 \mathrm{~g} / \mathrm{kg}$ of seed) prevented the insect infestation and there by registered higher seed germination. Similarly, Anahousur and Bidari (1973) reported higher seed germination in soybean by treating the seeds with thiram ( $2 \mathrm{~g} / \mathrm{kg}$ of seeds) even six months after storage.

Among the gamma irradiation treatments $\left(\mathrm{T}_{2}\right.$ to $\left.\mathrm{T}_{6}\right), \mathrm{T}_{6}(1000 \mathrm{~Gy})$ recorded the lowest seed germination (79.0 and $75 \%$ ) in bengal gram and black gram, respectively at initial month after storage indicating the inhibitory effect when used at higher dosage. While, decrease in seed germination $(69.5$ and $66.0 \%)$ at nine months after storage in Bengal gram and black gram, respectively (Table 1a and 2a). While, $\mathrm{T}_{2}$ (200 Gy) registered slightly higher seed germination (94.0 and $89.5 \%$ ) compared to control (90.5 and $85.3 \%)$ in bengal gram and black gram at initial month after storage. While over the storage period decrease in seed germination $\left(83.5\right.$ and $79.0 \%$ ) in $\mathrm{T}_{2}$ after nine months after storage in bengal gram and black gram, respectively. This stimulatory effect on seed germination at low dosage of gamma irradiation might be due to better oxygen uptake and dehydrogenase enzyme activity there by providing energy to the germinating embryo and overall increasing the capacity of metabolic activities as per (Krishnaswamy and Seshu, 1989). This may also be due to activation of RNA (Kuzin et al., 1975) or protein (Kuzin et al., 1976) synthesis which might have occurred during early stage of germination after irradiation of seeds. Similarly, Selvaraju (2001) observed that the low dose $(1 \mathrm{kr})$ of gamma irradiation improved the seed germination in three rice varieties when compared to untreated control. However, with an increase in the gamma irradiation dosage from 200 Gy $\left(\mathrm{T}_{2}\right)$ to 1000 Gy $\left(\mathrm{T}_{6}\right)$ the seed germination reduced drastically. The inhibitory effect at higher dosage could be as a result of greater loss of leachates due to enhanced membrane permeability (Krishnaswamy and Seshu., 1989). Hence, leaching of electrolytes was more in seeds exposed to higher dose of gamma irradiation $\left(\mathrm{T}_{6}-1000 \mathrm{~Gy}\right)$ than low dosage $\left(\mathrm{T}_{2}-200\right.$ Gy $)$ which reduced germinability accompanied with the reduction in the activities of dehydrogenase and alpha amylase enzymes. It could also be due to accumulation of non-volatile growth inhibitors in irradiated seeds (Rajarajeshwari, 2011). Similarly, Uma and Salimath (2001) reported a significant reduction in the seed germination 
potential of cow pea seeds with an increase in irradiation dosage (10 Kr to $60 \mathrm{Kr}$ ). Likewise, Narayan et al., (2014) noticed decrease in the seed germination with an increase in gamma irradiation dosage from 200 to $800 \mathrm{~Gy}$ and they also reported that the regeneration potential of callus derived from primary leaves of treated seeds improved at low dosage (200 to $400 \mathrm{~Gy})$. In the same line, Ariramana et al., (2014) in pigeon pea, Monica and Seetharaman (2014) in Lablab purpureus and Dhulgande et al., (2015) in pea reported inhibition of seed germination and seedling growth at higher doses or concentrations of mutagens. While, Muhammad Amjad and Muhammad Akbar (2002) reported higher electrical conductivity of onion seeds exposed to gamma irradiation $(10,20,40,80$ and 100 $\mathrm{Krad})$ than that of un irradiated seeds.

From the present study, significantly lower abnormal seedlings (1.5 and $2.5 \%$ ) and dead seeds $(0.8$ and $1.5 \%)$ were noticed in $\mathrm{T}_{9}$ (combination of melathion and thiram @ $2 \mathrm{~g} / \mathrm{kg}$ of seeds) compared to all other treatments and control $(2.5$ and $3.8 \%)$ and (1.0 and $6.0 \%)$ in bengal gram and black gram (Table 1a and 2a) at initial months after storage. However with the advancement of storage period there was increase in abnormal seedlings (8.3 and $9.0 \%$ ) and dead seeds (4.5 and $9.8 \%$ ) in $\mathrm{T}_{9}$ compare to control (9.0 and $9.8 \%)$ and $(6.0$ and $12.0 \%)$ at nine months after storage period in bengal gram and black gram, respectively. Further, the abnormal seedlings $(\%)$ and dead seeds $(\%)$ increased alarmingly with the increase in gamma irradiation dosage $\left(\mathrm{T}_{2}\right.$ to $\left.\mathrm{T}_{6}\right)$. Further, $\mathrm{T}_{6}(1000$ Gy) recorded the highest abnormal seedlings (14.8 and $16.3 \%$ ) and dead seeds (3.0 and 8.0 $\%)$ compared to control (2.5 and $3.8 \%)$ and (1.0 and $6.0 \%$ ) in bengal gram and black gram respectively, at initial month after storage. While, over the storage period drastic increase in abnormal seedlings (22.0 and 23.0 $\%)$ and dead seeds (9.0 and $14.5 \%)$ in $\mathrm{T}_{6}$ compared to control (9.0 and $9.8 \%)$ and (6.0 and $12.0 \%$ ) in bengal gram and black gram at nine month after storage, respectively was noticed. This might be due to gamma irradiation induced oxidative stress with over production of reactive oxygen species (ROS) such as super oxide radical, hydroxyl radical and hydrogen peroxide which reacts rapidly with almost all structural and functional organic molecules including proteins, lipids and nucleic acids causing disturbance in cellular metabolism (Salter and Hewitt., 1992). Similarly, Muhammad Amjad and Muhammad Akbar (2002) also noticed increase in abnormal seedlings with an increase in irradiation dose.

Among the different treatments, significantly higher shoot $(9.9$ and $10.2 \mathrm{~cm})$ and root $(16.7$ and $13.5 \mathrm{~cm}$ ) length were recorded by $\mathrm{T}_{9}$ (melathion + thiram @ $2 \mathrm{~g} / \mathrm{kg}$ of seeds) compared to all other treatments and control $(8.2$ and $8.9 \mathrm{~cm})$ and $(16.4$ and $12.7 \mathrm{~cm})$ in bengal gram and black gram (Table 1a and 2a) at initial month after storage, respectively. While, over the storage period decrease in shoot $(8.8$ and $9.0 \mathrm{~cm})$ and root length $(15.0$ and $11.9 \mathrm{~cm})$ in $\mathrm{T}_{9}$ compared to control $(6.9$ and $7.7 \mathrm{~cm})$ and $(14.5$ and $11.1 \mathrm{~cm})$ in bengal gram and black gram at nine months after storage, respectively. This might be due to the influence of fungicides which might have increased the phenol production and total sugars (Sindhan et al., 1996). The results are in line with the findings of Choudury et al., (2011) who reported significantly higher root and shoot length due to seed treatment with thiram and bavistin each at one gram per $\mathrm{kg}$ of seeds. Similarly, Ravikumar et al., (1987) reported that soybean seeds treated with melathion $(10 \mathrm{~g} / \mathrm{kg}$ of seeds) or in combination with thiram (2 $\mathrm{g} / \mathrm{kg}$ of seeds) prevented insect infestation and recorded higher shoot length. Among the gamma irradiation treatments, 1000 Gy $\left(\mathrm{T}_{6}\right)$ recorded the lower shoot length $(5.1$ and $5.9 \mathrm{~cm})$ and 
root length (11.0 and $8.6 \mathrm{~cm})$ compared to lower dosage $\mathrm{T}_{2}(8.2$ and $9.0 \mathrm{~cm})$ and $(15.9$ and $12.1 \mathrm{~cm})$ and control $(8.2$ and $8.9 \mathrm{~cm})$ and $(16.4$ and $12.7 \mathrm{~cm})$ in bengal gram and black gram respectively, at initial month after storage for shoot and root length. While, with the advancement of storage period decrease in shoot $(4.0$ and $4.8 \mathrm{~cm})$ and root length $(10.0$ and $7.4 \mathrm{~cm})$ in $\mathrm{T}_{6}$ compared to control $(6.9$ and $7.7 \mathrm{~cm})$ and $(14.5$ and $11.1 \mathrm{~cm})$ in bengal gram and black gram, respectively at nine months after storage period was noticed. This decrease in shoot and root lengths at higher dose was probably due to reduced mitotic activity of the meristematic tissues (Shakoor et al., 1978 and Khalil et al., 1986). Reduction in seedling growth at higher dosage has been attributed to the changes in the level of auxin and ascorbic acid contents and also due to physiological and biochemical disturbances (Gunekal and Sparrow, 1954), changes in the enzyme activity (Alduous and Stewart, 1952), chromosomal breakage and mitotic inhibition (Sparrow and vans, 1961) and inhibition of DNA synthesis (Mikaelson, 1968). These results are in line with the findings of Uma and Salimath (2001) who reported a significant reduction in root and shoot length of cow pea seeds with an increase in the irradiation dosage (10 Kr to $60 \mathrm{Kr}$ ). Similarly, Aparna et al., (2013) reported a significant reduction in root and shoot length of groundnut seeds at higher dosage of gamma irradiation compared to un irradiated control.

Among the different treatments significantly higher seedling dry weight (2.913 and 1.098 g) was recorded by $\mathrm{T}_{9}$ (combination of melathion and thiram @ $2 \mathrm{~g} / \mathrm{kg}$ of seeds) compared to all other treatments and control (2.603 and $1.030 \mathrm{~g}$ ) in bengal gram and black gram at initial month after storage respectively (Table 1a and 2a). While, over the storage period decrease in seedling dry weight $(2.748$ and $0.933 \mathrm{~g})$ in $\mathrm{T}_{9}$ compared to control $(2.438$ and $0.870 \mathrm{~g}$ ) in bengal gram and black gram at nine months after storage, respectively was noticed. Similarly, $\mathrm{T}_{9}$ was also able to record significantly higher seedling vigour index (2485 and 2154) compared to all other treatments and control (2226 and 1841) in bengal gram and black gram at initial month after storage. This might be due to longer shoot and root length recorded in our study which had a direct correlation with seedling dry weight and seedling vigour index. The fungicide protected the seed deterioration by reducing the fungal invasion and favoured the seed germination and other quality parameters (Sundaresh et al., 1987). These results are in line with the findings of Basavaraj et al., (2008) who reported that onion seeds coated with polymer (@12 ml)+thiram (@2 g / kg of seeds) recorded higher seedling dry weight and seedling vigour index. Among the gamma irradiation treatments (Table 1a and 2a), 1000 Gy $\left(\mathrm{T}_{6}\right)$ recorded the lower seedling dry weight (2.388 and $0.773 \mathrm{~g})$ and seedling vigour index (1332 and 1023) compared to the lower dosage, $\mathrm{T}_{2}(2.735$ and $1.073 \mathrm{~g})$ and (2265 and 1892) and control (2.603 and 1.030 g) and (2226 and 1841) in bengal gram and black gram respectively, at initial months after storage for seedling dry weight and seedling vigour index. While, with the advancement of storage period reduced the seedling dry weight (2.318 and 0.605) and seedling vigour index (1029 and 754) in $\mathrm{T}_{9}$ compared to lower dosage $\mathrm{T}_{2}$ (2.425 and 0.865) and (1763 and 1448) and control (2.438 and 0.870) and (1770 and 1478) in bengal gram and black gram at nine months after storage, respectively for seedling dry weight and seedling vigour index. This reduction in seedling dry weight and seedling vigour index at higher dosage might be due to shorter root and shoot length registered in our study which had a direct correlation with dry weight and seedling vigour index. Due to inhibition of mitosis and enzyme activities it is more likely that the reserve food was utilized less efficiently at higher dose of irradiation which might have 
resulted in reduction of seedling fresh and dry weight (Alduous and Stewert, 1952). The other causes for reduction in dry matter may be inhibition of cell elongation. The results are in line with the findings of Veeresh et al., (1995) who recorded an increase in shoot fresh weight of winged bean at lower dose, however decreased at higher dose. Similarly, Aparna et al., (2013) in groundnut and Radha and Uma (2015) in finger millet reported reduction in seedling vigour index at higher dosage.

Similarly, $\mathrm{T}_{9}$ also recorded significantly lower mean germination time (1.19 and 1.31) compared to all other treatments and control (1.34 and 1.51) in bengal gram and black gram at initial month after storage, respectively (Table 1a and 2a). While, over the storage period increase in mean germination time (2.10 and 2.34) in $T_{9}$ compared to control (2.37 and 2.40) in bengal gram and black gram at nine months after storage, respectively was observed. While, the gamma irradiation treatments delayed the mean germination time with an increase in dosage and $\mathrm{T}_{6}(1000 \mathrm{~Gy})$ recorded the higher mean germination time (1.64 and 1.67) in bengal gram and black gram respectively, at initial month after storage. While, advancement of storage period increased the mean germination time (2.57 and 2.59) in $\mathrm{T}_{6}$ compared to control (2.37 and 2.40) in bengal gram and black gram at nine months after storage, respectively was observed. This may be ascribed to histological, cytological changes, disruption and disorganization of seed layer and also generation of free radicals resulting in metabolic disorders in the germinating seeds (Lokesha et al., 1992)and inhibitory effect of gamma rays on seed germination (Majeed $e t$ al., 2010). These results are also in line with the findings of Majeed et al., (2010) who found that the mean germination time of Lepidum sativam was significantly delayed at higher dose of gamma rays. From the present study, it was observed that, $\mathrm{T}_{9}$ (combination of melathion and thiram each @ $2 \mathrm{~g} / \mathrm{kg}$ of seeds) recorded significantly higher germination rate index (7701 and 7198) compared to all other treatments and control (6809 and 5950) in bengal gram and black gram at initial month after storage, respectively. While, the germination rate index decreased (4684 and 3946 ) in $T_{9}$ compared to control (4219 and 3658) in bengal gram and black gram at nine months after storage, respectively (Table $1 \mathrm{~b}$ and $2 b$ ).

Similarly, the peak value of germination was also significantly higher in $\mathrm{T}_{9}$ (44.0 and 24.5) compared to all other treatments and control (35.0 and 21.8) in bengal gram and black gram at initial month after storage, respectively (Table $1 \mathrm{~b}$ and $2 \mathrm{~b}$ ). While, the peak value of germination in $\mathrm{T}_{9}$ decreased (23.5 and 20.0) compared to control (18.0 and 16.5) in bengal gram and black gram at nine months after storage, respectively. Among the gamma irradiation treatments, 1000 Gy $\left(\mathrm{T}_{6}\right)$ recorded the least germination rate index (6071 and 5151) and peak value of germination (27.5 and 15.3) compared to the lower dosage $T_{2}(7029$ and 6020) and (36.5 and 22.8) and control (6809 and 5950) and (35.0 and 21.8) in bengal gram and black gram respectively, at initial month after storage for germination rate index and peak value of germination. While, the germination rate index decreased (2784 and $3067)$ and peak value of germination (13.5 and $9.5)$ in $T_{6}$ compared to lower dosage $T_{2}(4245$ and 3779) and (19.0 and 17.0) and control (4219 and 3658) and (18.0 and 16.5) in bengal gram and black gram at nine months after storage, respectively. These physiological changes due to radiation increases plant sensitivity to gamma rays which in turn reduce the synthesis of endogenous growth regulators, especially cytokinins (Kiong et al., 2008) there by reduced the germination parameters with corresponding decline in growth of the plants. 
Table.1a Influence of gamma irradiation and seed treatment chemicals on seed quality parameters of bengal gram

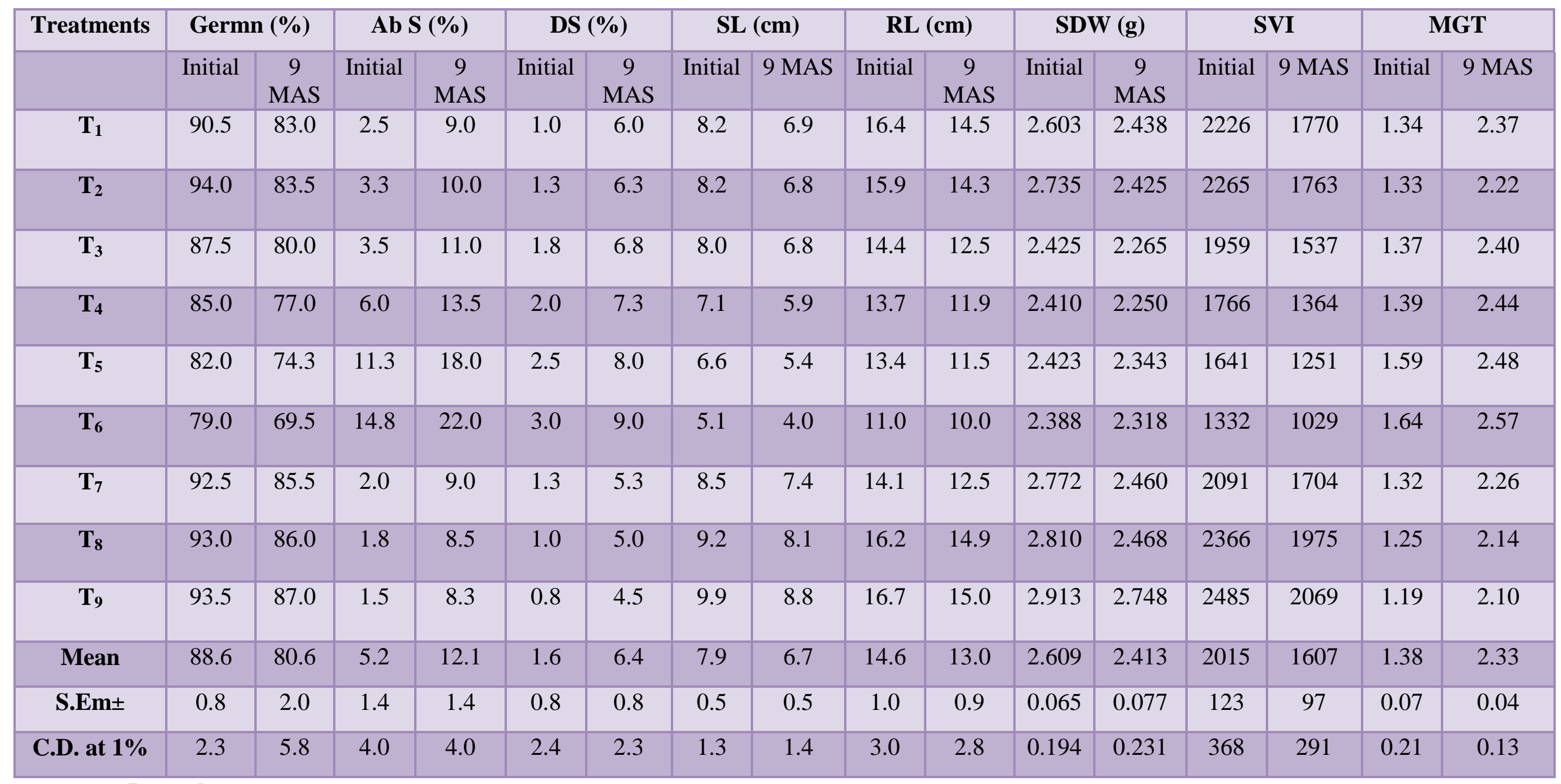

\section{Legends}

$\mathbf{T}_{1}$ - Control

$\mathbf{T}_{2}-200 \mathrm{~Gy}$
$\mathbf{T}_{3}-400$ Gy

$\mathbf{T}_{4}-600 \mathrm{~Gy}$
$\mathbf{T}_{5} . .800 \mathrm{~Gy}$

$\mathbf{T}_{6}-1000 \mathrm{~Gy}$
$\mathbf{T}_{7}$ - Melathion $(2 \mathrm{~g} / \mathrm{kg}$ of seed $)$ $\mathbf{T}_{\mathbf{8}}$ - Thiram (2 $\mathrm{g} / \mathrm{kg}$ of seed)
$\mathbf{T}_{\mathbf{9}^{-}}$Melathion+Thiram (each $2 \mathrm{~g} / \mathrm{kg}$ of seed) MAS- Months after storage 
Table.1b Influence of gamma irradiation and seed treatment chemicals on seed quality parameters of bengal gram, cont..

\begin{tabular}{|c|c|c|c|c|c|c|c|c|c|c|c|c|c|c|c|}
\hline \multirow[t]{2}{*}{ Treatments } & \multicolumn{2}{|c|}{ GRI } & \multicolumn{2}{|c|}{ PVG } & \multicolumn{2}{|c|}{ DH } & \multicolumn{2}{|c|}{$\begin{array}{c}\alpha-\text { amylse } \\
\text { enzyme } \\
\text { activity }(\mathbf{m m})\end{array}$} & \multicolumn{2}{|c|}{$\mathrm{EC}\left(\mathrm{dSm}^{-1}\right)$} & \multicolumn{2}{|c|}{ Insect egg (\%) } & \multicolumn{2}{|c|}{$\begin{array}{c}\text { Seed damage } \\
(\%)\end{array}$} & \multirow{2}{*}{$\begin{array}{r}\begin{array}{r}\text { Weight } \\
\text { loss (\%) }\end{array} \\
9 \text { MAS }\end{array}$} \\
\hline & Initial & $9 \mathrm{MAS}$ & Initial & 9 MAS & Initial & $9 \mathrm{MAS}$ & Initial & 9 MAS & Initial & $8 \mathrm{MAS}$ & $6 \mathrm{MAS}$ & 9 MAS & $6 \mathrm{MAS}$ & 9 MAS & \\
\hline $\mathbf{T}_{1}$ & 6809 & 4219 & 35.0 & 18.0 & 2.035 & 1.489 & 22.9 & 20.3 & 0.603 & 0.651 & 10.0 & 23.0 & 4.17 & 12.92 & 7.76 \\
\hline $\mathbf{T}_{2}$ & 7029 & 4245 & 36.5 & 19.0 & 2.161 & 1.570 & 23.9 & 20.4 & 0.607 & 0.665 & 7.0 & 15.0 & 2.30 & 4.79 & 1.22 \\
\hline $\mathbf{T}_{\mathbf{3}}$ & 6730 & 4062 & 32.5 & 17.0 & 1.992 & 1.321 & 22.7 & 18.2 & 0.645 & 0.673 & 0.0 & 12.0 & 0.00 & 4.38 & 0.38 \\
\hline $\mathbf{T}_{4}$ & 6383 & 3684 & 31.0 & 16.0 & 1.941 & 1.319 & 22.3 & 17.7 & 0.656 & 0.695 & 0.0 & 10.0 & 0.00 & 2.92 & 0.36 \\
\hline $\mathbf{T}_{5}$ & 6100 & 3680 & 30.0 & 15.0 & 1.931 & 1.289 & 22.0 & 17.4 & 0.659 & 0.705 & 0.0 & 7.0 & 0.00 & 2.09 & 0.06 \\
\hline $\mathbf{T}_{6}$ & 6071 & 2784 & 27.5 & 13.5 & 1.622 & 1.136 & 21.0 & 16.9 & 0.749 & 0.795 & 0.0 & 5.0 & 0.00 & 1.46 & 0.02 \\
\hline $\mathbf{T}_{7}$ & 7383 & 4380 & 39.5 & 21.5 & 2.430 & 1.742 & 25.5 & 21.4 & 0.584 & 0.621 & 0.0 & 0.0 & 0.00 & 0.00 & 0.00 \\
\hline $\mathbf{T}_{8}$ & 7581 & 4545 & 42.5 & 23.0 & 2.499 & 1.775 & 25.9 & 22.5 & 0.566 & 0.608 & 0.0 & 0.0 & 0.00 & 0.00 & 0.00 \\
\hline $\mathbf{T}_{9}$ & 7701 & 4684 & 44.0 & 23.5 & 2.520 & 1.816 & 26.5 & 23.5 & 0.551 & 0.598 & 0.0 & 0.0 & 0.00 & 0.00 & 0.00 \\
\hline Mean & 6865 & 4031 & 35.4 & 18.5 & 2.126 & 1.495 & 23.6 & 19.8 & 0.624 & 0.668 & 1.9 & 8.0 & 0.72 & 3.17 & 1.09 \\
\hline S.Em \pm & 304 & 240 & 2.2 & 2.3 & 0.285 & 0.106 & 1.2 & 1.0 & 0.004 & 0.004 & 0.9 & 1.9 & 0.07 & 0.02 & 0.06 \\
\hline C.D. at $1 \%$ & 912 & 719 & 6.6 & 6.9 & 0.855 & 0.318 & 3.6 & 3.0 & 0.012 & 0.011 & 2.7 & 5.7 & 0.22 & 0.06 & 0.19 \\
\hline
\end{tabular}

Legends $\mathbf{T}_{1}$ - Control $\quad \mathbf{T}_{\mathbf{3}}-400 \mathrm{~Gy} \quad \mathbf{T}_{5} . .800 \mathrm{~Gy}$ $\mathbf{T}_{2}-200 \mathrm{~Gy} \quad \mathbf{T}_{\mathbf{4}}-600 \mathrm{~Gy} \quad \mathbf{T}_{\mathbf{6}}-1000 \mathrm{~Gy}$
$\mathbf{T}_{7}$ - Melathion $(2 \mathrm{~g} / \mathrm{kg}$ of seed)

$\mathbf{T}_{\mathbf{8}}$ - Thiram (2 $\mathrm{g} / \mathrm{kg}$ of seed)
$\mathbf{T}_{\mathbf{9}^{-}}$Melathion+Thiram (each $2 \mathrm{~g} / \mathrm{kg}$ of seed) MAS- Months after storage 
Table.2a Influence of gamma irradiation and seed treatment chemicals on seed quality parameters of black gram

\begin{tabular}{|c|c|c|c|c|c|c|c|c|c|c|c|c|c|c|c|c|}
\hline Treatments & Gern & n $(\%)$ & Ab & $(\%)$ & DS & $(\%)$ & & (cm) & RI & (cm) & SD & $N(g)$ & & VI & & GT \\
\hline & Initial & 9 MAS & Initial & 9 MAS & Initial & $9 \mathrm{MAS}$ & Initial & 9 MAS & Initial & 9 MAS & Initial & 9 MAS & Initial & 9 MAS & Initial & 9 MAS \\
\hline $\mathbf{T}_{1}$ & 85.3 & 78.5 & 3.8 & 9.8 & 6.0 & 12.0 & 8.9 & 7.7 & 12.7 & 11.1 & 1.030 & 0.870 & 1841 & 1478 & 1.51 & 2.40 \\
\hline $\mathbf{T}_{2}$ & 89.5 & 79.0 & 4.0 & 11.0 & 6.5 & 12.5 & 9.0 & 7.5 & 12.1 & 10.9 & 1.073 & 0.865 & 1892 & 1448 & 1.40 & 2.40 \\
\hline $\mathbf{T}_{3}$ & 84.0 & 75.8 & 4.8 & 11.5 & 6.8 & 13.3 & 8.5 & 7.3 & 11.1 & 9.6 & 0.948 & 0.793 & 1647 & 1282 & 1.58 & 2.46 \\
\hline $\mathbf{T}_{4}$ & 83.0 & 75.5 & 7.3 & 14.0 & 7.0 & 13.5 & 8.3 & 7.1 & 10.0 & 8.7 & 0.923 & 0.763 & 1519 & 1193 & 1.61 & 2.47 \\
\hline $\mathbf{T}_{5}$ & 80.0 & 72.0 & 12.8 & 20.0 & 7.3 & 14.0 & 7.3 & 6.0 & 9.6 & 8.2 & 0.848 & 0.693 & 1349 & 1021 & 1.65 & 2.49 \\
\hline $\mathbf{T}_{6}$ & 75.0 & 66.0 & 16.3 & 23.0 & 8.0 & 14.5 & 5.9 & 4.8 & 8.6 & 7.4 & 0.773 & 0.605 & 1023 & 754 & 1.67 & 2.59 \\
\hline $\mathbf{T}_{7}$ & 90.3 & 82.5 & 3.0 & 10.0 & 3.0 & 11.8 & 9.3 & 8.2 & 12.7 & 11.6 & 1.063 & 0.900 & 1983 & 1634 & 1.36 & 2.38 \\
\hline $\mathbf{T}_{8}$ & 90.8 & 83.3 & 2.8 & 9.5 & 1.8 & 10.0 & 9.9 & 8.8 & 13.2 & 11.7 & 1.090 & 0.918 & 2093 & 1702 & 1.34 & 2.37 \\
\hline $\mathbf{T}_{9}$ & 91.0 & 83.8 & 2.5 & 9.0 & 1.5 & 9.8 & 10.2 & 9.0 & 13.5 & 11.9 & 1.098 & 0.933 & 2154 & 1755 & 1.31 & 2.34 \\
\hline Mean & 85.4 & 77.4 & 6.3 & 13.1 & 5.3 & 12.4 & 8.6 & 7.4 & 11.5 & 10.1 & 0.983 & 0.816 & 1722 & 1363 & 1.49 & 2.43 \\
\hline S.Em \pm & 1.2 & 2.0 & 1.0 & 1.4 & 0.9 & 0.9 & 0.4 & 0.5 & 1.0 & 0.7 & 0.033 & 0.059 & 101 & 64 & 0.06 & 0.092 \\
\hline C.D. at $1 \%$ & 3.4 & 5.7 & 3.0 & 4.2 & 2.7 & 2.7 & 1.3 & 1.3 & 2.8 & 2.1 & 0.099 & 0.171 & 303 & 191 & 0.18 & 0.276 \\
\hline
\end{tabular}

\section{Legends}

$\mathbf{T}_{1}$ - Control

$\mathbf{T}_{2}-200 \mathrm{~Gy}$
$\mathbf{T}_{3}-400$ Gy

$\mathbf{T}_{\mathbf{4}}-600 \mathrm{~Gy}$
$\mathbf{T}_{5} .-800 \mathrm{~Gy}$

$\mathbf{T}_{6}-1000$ Gy
$\mathbf{T}_{7}$ - Melathion $(2 \mathrm{~g} / \mathrm{kg}$ of seed)

$\mathbf{T}_{\mathbf{8}}$ - Thiram (2 $\mathrm{g} / \mathrm{kg}$ of seed)

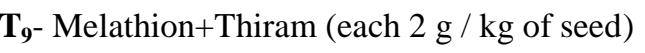
MAS- Months after storage 
Table.2b Influence of gamma irradiation and seed treatment chemicals on seed quality parameters of black gram, cont......

\begin{tabular}{|c|c|c|c|c|c|c|c|c|c|c|}
\hline \multirow[t]{2}{*}{ Treatments } & \multicolumn{2}{|c|}{ GRI } & \multicolumn{2}{|c|}{ PVG } & \multicolumn{2}{|c|}{ DH } & \multicolumn{2}{|c|}{$\begin{array}{l}\alpha \text { - amylse enzyme } \\
\text { activity }(\mathbf{m m}) *\end{array}$} & \multicolumn{2}{|c|}{$\mathrm{EC}\left(\mathrm{dSm}^{-1}\right) *$} \\
\hline & Initial & $9 \mathrm{MAS}$ & Initial & 9 MAS & Initial & 9 MAS & Initial & 9 MAS & Initial & $8 \mathrm{MAS}$ \\
\hline $\mathbf{T}_{1}$ & 5950 & 3658 & 21.8 & 16.5 & 1.419 & 1.323 & 22.5 & 17.0 & 0.532 & 0.581 \\
\hline $\mathbf{T}_{2}$ & 6020 & 3779 & 22.8 & 17.0 & 1.448 & 1.330 & 23.3 & 17.4 & 0.538 & 0.586 \\
\hline $\mathbf{T}_{\mathbf{3}}$ & 5921 & 3588 & 20.3 & 13.5 & 1.393 & 1.104 & 21.0 & 15.9 & 0.563 & 0.608 \\
\hline $\mathbf{T}_{4}$ & 5885 & 3288 & 17.8 & 11.0 & 1.382 & 1.060 & 20.9 & 14.6 & 0.585 & 0.626 \\
\hline $\mathbf{T}_{5}$ & 5368 & 3205 & 15.5 & 10.0 & 1.340 & 1.031 & 20.0 & 13.3 & 0.593 & 0.647 \\
\hline $\mathbf{T}_{6}$ & 5151 & 3067 & 15.3 & 9.5 & 1.328 & 1.029 & 19.1 & 11.8 & 0.595 & 0.655 \\
\hline $\mathbf{T}_{7}$ & 6053 & 3813 & 23.0 & 17.0 & 1.506 & 1.340 & 25.0 & 17.7 & 0.52 & 0.559 \\
\hline $\mathbf{T}_{8}$ & 6550 & 3896 & 23.3 & 18.0 & 1.579 & 1.399 & 25.6 & 17.9 & 0.508 & 0.546 \\
\hline $\mathbf{T}_{9}$ & 7198 & 3946 & 24.5 & 20.0 & 1.720 & 1.576 & 26.0 & 18.8 & 0.481 & 0.532 \\
\hline Mean & 6011 & 3582 & 20.4 & 14.7 & 1.457 & 1.244 & 22.6 & 16.0 & 0.546 & 0.593 \\
\hline S.Em \pm & 238 & 288 & 1.4 & 3.0 & 0.218 & 0.129 & 1.4 & 0.9 & 0.003 & 0.003 \\
\hline C.D. at $1 \%$ & 714 & 864 & 4.4 & 9.0 & 0.654 & 0.387 & 4.2 & 2.9 & 0.009 & 0.007 \\
\hline
\end{tabular}

*Eight months after storage

Legends

$\mathrm{T}_{1}$ - Control

$\mathbf{T}_{\mathbf{3}}-400$ Gy

$\mathbf{T}_{2}-200 \mathrm{~Gy}$

$\mathbf{T}_{4}-600 \mathrm{~Gy}$

$\mathbf{T}_{5} \ldots 800 \mathrm{~Gy}$

$\mathbf{T}_{6}-1000$ Gy
$\mathbf{T}_{7}$ - Melathion $(2 \mathrm{~g} / \mathrm{kg}$ of seed)

$\mathbf{T}_{\mathbf{8}}$ - Thiram (2 $\mathrm{g} / \mathrm{kg}$ of seed)
$\mathbf{T}_{9^{-}}$- Melathion+Thiram (each $2 \mathrm{~g} / \mathrm{kg}$ of seed) MAS- Months after storage 
These results are in line with the earlier findings of Cheema and Atta (2003) who reported decreased in peak value of germination with an increase in gamma irradiation dose. Similarly, Aparna et al., (2013) reported decrease in speed of germination, mean daily germination, peak and germination value significantly with an increase in radiation dose.

Significantly higher dehydrogenase enzyme activity (2.520 and 1.720) was recorded by $\mathrm{T}_{9}$ (combination of melathion and thiram @ $2 \mathrm{~g} /$ $\mathrm{kg}$ of seeds) compared to all other treatments and control (2.035 and 1.419) in bengal gram and black gram at initial month after storage respectively (Table $1 b$ and $2 b$ ). While, the dehydrogenase enzyme activity decreased (1.816 and 1.576) in $\mathrm{T}_{9}$ compared to control (1.489 and 1.323) in bengal and black gram at eight months after storage, respectively. Similarly, the alpha amylase enzyme activity was also higher in $\mathrm{T}_{9}(26.5$ and $26.0 \mathrm{~mm})$ compared to all other treatments and control (22.9 and $22.5 \mathrm{~mm}$ ) in bengal gram and black gram at initial month after storage respectively. While the alpha amylase enzyme activity decreased $(23.5$ and $18.8 \mathrm{~mm})$ in $\mathrm{T}_{9}$ compared to control (20.3 and $17.0 \mathrm{~mm})$ in bengal gram and black gram at eight months after storage, respectively. Among the gamma irradiation treatments, $1000 \mathrm{~Gy}\left(\mathrm{~T}_{6}\right)$ recorded the lowest dehydrogenase (1.622 and 1.328) and alpha amylase (21.0 and $19.1 \mathrm{~mm})$ enzyme activities compared to the lower dosage, $\mathrm{T}_{2}$ (2.161 and 1.448) and (23.9 and $23.3 \mathrm{~mm}$ ) and control (2.035 and 1.419) and (22.9 and $22.5 \mathrm{~mm}$ ) in bengal gram and black gram respectively, at initial months after storage. While, the dehydrogenase (1.136 and 1.029) and alpha amylase (16.9 and $11.8 \mathrm{~mm}$ ) enzyme activities decreased in $\mathrm{T}_{6}$ compared to lower dosage $\mathrm{T}_{2}(1.570$ and 1.330) and (20.4 and $17.4 \mathrm{~mm}$ ) and control (1.489 and $1.323)$ and (20.3 and $17.0 \mathrm{~mm})$ in bengal gram and black gram. This might be due to decline in the activity of amylases in seed which reduces the rate of starch hydrolysis and thus might have slowed down the germination process (Koksel et al., 1998). These results are in line with the findings of Ivan et al., (2012) who reported that irradiation of malt caused a significant reduction in alpha and beta amylase activity. Similarly, Delia et al., (2013) noticed that the biochemical differences based on photosynthetic pigment content revealed an inverse relationship to the dosage of exposure.

The insect egg and seed damage (\%) were not at all noticed in black gram in any of the treatments even at even nine months after storage. Hence, the data for the same is not presented in the Table $2 \mathrm{~b}$. However, in bengal gram (Table 1b), they were noticed from six months after storage in control- $\mathrm{T}_{1}(10.0 \%)$ and low dosage of gamma irradiation $\left(\mathrm{T}_{2}-200\right.$ Gy-7.0 \%). Finally, at the end of nine months storage period, treating the seeds with melathion- $\mathrm{T}_{7}$, Thiram- $\mathrm{T}_{8}$ and combination of melathion and thiram- $T_{9}$ were effective in control of cent per cent insect eggs there by without any seed damage and consequently no weight loss compared to control with 23.00, 12.92 and 7.76 per cent insect egg, seed damage and weight loss, respectively. This might be due to treating the seeds with insecticides and fungicides might have inhibited hatching of eggs resulting no emergence of adults and thereby absence of pinholes on seeds. The results are in line with findings of Pramanik and Sardhar (2006) who reported lower number of emerged adults, reduction in seed damage and weight loss in insecticide treated seeds of green gram and bengal gram. Similarly, Radhakrishnan et al., (1983) reported 90 per cent pulse bruchid mortality with dust formulation of five per cent melathion.

Further, exposing the seeds to gamma irradiation $\left(T_{2}\right.$ to $\left.T_{6}\right)$ showed a significant 
reduction in insect egg $(\%)$, seed damage $(\%)$ with an increase in gamma radiation dosage even after nine months of storage in Bengal gram and hence, the highest dosage of gamma irradiation (T6-100 Gy) recorded the least seed damage $(1.46 \%)$ and weight loss $(0.02 \%)$ only. This might be due to disinfecting action of gamma irradiation on seeds and thereby might have controlled the insects which lead to complete mortality of insects and also prevent hatching of eggs on seed surface leading to neither damage nor reduction in weight loss of the seed. The results are in line with the findings of Richard and Patrick (2014) who reported 100 per cent mortality of Sitophilus zeamais and Callosobruchus maculatus when exposed to gamma radiation at $300 \mathrm{~Gy}$ and $500 \mathrm{~Gy}$. In the same line, Byun et al., (1988) evaluated the effect of gamma irradiation for controlling infestation of rice weevil (Sitophilus oryzae) and observed complete mortality of egg and larval stages at $0.05 \mathrm{kGy}$. While, Kareem and Baki (2013) observed severe reduction in fecundity and fertility of pest in rice in 25 days old larvae treated with a gamma dose of 80 Gy.

In conclusion, seed treatment with the combination of melathion and thiram each at the rate of $2 \mathrm{~g}$ per $\mathrm{kg}$ of seed was found effective in maintaining the longevity of bengal gram and black gram seeds under ambient storage conditions. Among the different dosage of gamma irradiation, the lower dosage (200 Gy) significantly improved the seed quality both in bengal gram and black gram during storage.

\section{Acknowledgement}

The authors acknowledge University of Agricultural Sciences, Raichur, Karnataka, India for providing financial assistance under demand drive project for carrying out the research work.

\section{References}

Abdul-Baki, A. A. and Anderson, J. D. 1973. Vigour determination in soybean seeds by multiple criteria. Crop Sci. 13: 630-633.

Aldous, J. G. and Stewart, K. D. 1952. action of $\mathrm{X}$-rays upon some enzymes of the living yeast cells. Rev. Can. Biol. 11: 49.

Anahosur, K. H. and Bidari, R. V. 1973. Role of toxin of seed micro-flora in soybean storage. Cur. Res. 31: 130-131.

Anonymous, 2016. Area, production and productivity of major pulses (agropedia.iitk.ac.in).

Aparna, M., C. Anurag, M. Sreedhar, D. Pavan kumar, P. Venu Babu and Singhal, R. H. 2013. Impact of gamma rays on the seed germination and seedling parameters of Ground nut (Arachis hypogaea L.). Asian J. Exp. Biol. Sci. 4(1): 61-68.

Ariramana, M., S. Gnanamurthy, D. Dhanavelb, T. Bharathi. and Murugan S. 2014. Mutagenic effect on seed germination, seedling growth and seedling survival of Pigeon pea (Cajanus cajan (L.) Millsp) Int. Letters Natural Sci. 21: 41-49.

Ashraf, M. 2009. Biotechnological approach of improving plant salt tolerance using antioxidants as markers. Biotechnol. Adv. 27: 84-93.

Ashraf, M., A. A. Cheema, M. Rashid. and Qamar, Z. 2003. Effect of gamma rays on M1 generation in Basmati rice. Pak. J. Bot. 35(5): 791-795.

Aslam, M., 2004. Pest status of stored chickpea beetle, Callosobruchus chinensis L. on chickpea. J. Entomol. 1(1): 28-33.

Azimi, R., H. Feizi. and Hosseini, M. K. 2013. Can bulk and nanosized titanium dioxide particles improve seed germination features of wheat grass (Agropyron desertorum). Notule Scientia Biol. 5 (3): 325-331.

Basavaraj, B. O., N. K. Biradar Patil, B. S. Vyakarnal, N. Basavaraj, B. B. Channappagoudar. and Hunje, R. 2008. Effect of fungicide and polymer coating 
on storability of onion seeds. Karnataka J. Agric. Sci. 21(2): 212-218.

Borzouei, A., M. Kafi, M. Khazaei, B. Naseriyan and Majdabadi, B. 2010. Effect of gamma radiation on germination and physiological aspects of wheat (Triticum aestivum L.) seedlings. Pak. J. Bot. 42 (4): 2281- 2290.

Byun, M. W., J. H. Kwon, B. S. Cha, K. H. Chung. and Cho, H. C. 1988. Control of insects on stored rice grain by gamma irradiation. J. Korean Agric. Chemical Society. 31(2): 143-146.

Cheema, A. A. and Atta, B. M. 2003. Radio sensitivity studies in basmati rice. Pakistan J. Bot. 35(2): 197- 207.

Choudury, M. M., C. M. Rajanna, T. D. Silva. and Balakrishna, 2011. Influence of packaging materials and seed treatment on physiological attributes during storage of rice (Oryza sativa L.). Seed Sci. Biotechnol. 5(1): 15-20.

Delia, M., D. Grigore, C. Constantin. and Victoria, C. 2013. Gamma radiation effects on seed germination and pigment content and ESR study of induced free radicals in maize (Zea mays). J. Biol. Phys. 39: 625-634.

Dhulgande, G. S., D. S. Ghogare. and Dhale, D. A. 2015. Mutagenic effect on seed germination, seedling growth and seedling survival of pea (Pisum sativum L.). Int. J. Curr. Res. Biosci. Plant Biol. 2(4): 59-64.

Gairola, K. C., A. R. Nautiyal. and Dwivedi, A. K. 2011. Effect of temperatures and germination media on seed germination of Jatropha curcas. Adv. Biores. 2(2): 66-71.

Gunkel, and Sparrow, A. G. 1954. Aberrant growth in plants induced by ionizing radiation Brookhaven Symp. Biol. 6: 252279.

Harris, K. L. and Lindblad, C. J. 1978. A manual of methods for the evaluation of post harvest losses. American Assoc. Cereal. Chem. pp: 75-79.

ISTA., 2013. International rules of seed testing. Seed Sci. and Tech. 27:25-30.
Ivan, M. M., M. B. K. Charles, Muyanja., B. B. Yusuf, B. S. Reidar, L. Thor, A. Judith A and Narvhus., 2012. Gamma irradiation of sorghum flour: Effects on microbial inactivation, amylase activity, fermentability, viscosity and starch granule structure. Radiation Physics and Chemistry., 81: 345-351.

Kareem, A. A. and Baki, M. A. 2013. Gamma irradiation effects on larvae of the rice moth, Corcyra cephalonica (Staint) (Lepidoptera-Pyralidae). Entomol. Nematol. 5(4): 45-49.

Khalil, S. J., S. Rehman, K. Afridi. and Jan, M. T. 1986. Damage induced by gamma irradiation in morphological and chemical characteristics of barley. Sarhad J. Agric. 2: 45-54.

Kim, J. H., M. H. Baek, B. Y. Chung, S. G. Wi. and Kim, J. S. 2004. Alterations in the photosynthesis pigments and antioxidant machineries of red pepper (Capsicum annuит L.) seedlings from gammairradiated seeds. J. Plant Biotechnol. 47: 314-321.

Kiong, A., A. Ling Pick, S. H. Grace Lai and Harun, A. R. 2008. Physiological responses of Orthosiphon stamineus plantlets to gamma irradiation. AmericanEurasian J. Sustain. Agric. 2(2): 135-149.

Kittock, D. L. and Law, A. G. 1968. Relationship of seedling vigour, respiration and tetrazolium chloride reduction by germination of wheat seeds. Agron. J. 60: 286-288.

Koksel, H., S. Celik. and Ozkara, R. 1998. Effects of gamma irradiation of barley and malt on malting quality. J. Inst. Brew. 104: 89-92.

Kovacs, E and Keresztes, A. 2002. Effect of gamma and UV-B/C radiation on plant cell. Micron. 33: 199-210.

Krishnaswamy, V. and Seshu, D. V. 1989. Seed germination rate and associated characters in rice. Crop Sci. 29: 904-908.

Kuzin, A. M., M. E. Vagabova. and Prinak Mirolyubov, V. N. 1975. Molecular mechanisms of the stimulating effect of ionizing radiation on seed. Activation of 
RNA synthesis. Radiobiologiya. 15: 747750.

Kuzin, A. M., M. E. Vagabova. and Revin, A. F. 1976. Molecular mechanisms of thestimulating action of ionizing radiation on seeds. 2. Activation of protein and high molecular RNA synthesis. Radiobiologiya. 16: 259-261.

Lokesha, R., R. Vasudeva, H. E. Shashidhar. and Reddy, A. N. Y. 1992. Radiosensitivity of Bambusa arundinacea to gamma rays. J. Trop. Forest Sci. 6(4): 444- 450

Majeed, A., U. R. Asif, H. A. Khan. and Muhammad, Z. 2010. Gamma irradiation effects on irradiation effects on some growth parameters of Lepidium sativum L. J. Agricul. and Biol. Sci. 5(1): 39- 42.

Mikaleson, K. 1968. Effect of fast neutrons on seedling growth and metabolism in barley. In: Neutron irradiation of seeds. II.IAEA, Vienna, pp.63-70.

Milosevic, M. M., Vujakovic, D. and Karagic, 2010. Vigour test as indicators of seed viability. Genetika. 42(1): 103-118.

Monica, S. and Seetharaman, N. 2014. Effect of physical and chemical mutagens on seed germination and seedling growth of garden bean, J. Chem. Biol. Phy. Sci. 5(1): 815-822.

Mudaris, M. A. 1998. Notes on various parameters recording the speed of seed germination. Der Tropenlandwirt. 99: 147-154.

Muhammad Amjad. and Muhammad Akbar, A. 2002. Effect of gamma radiation on onion (Allium cepa L.) seed viability germination potential, seedling growth and morphology. Pak. J. Agric. S. 39(3): 125-132.

Narayan, S., S. N. Saxena, M. L. Jakhar, and Sharma, R. 2014. Enhancement of regeneration in moth bean (Vigna aconitifolia) through gamma irradiation. Legume Res. 38(4): 519-523.
Pramanik, M. Z. A. and Sardar, M. A. 2006. Application of insecticides on eggs of Callosobruchus chinensis L. using different types of pulse seeds. J. Agricul and Rural Develop., 14(1): 1810-1860.

Rabie, K., S. Shenata. and Bondok, M. 1996. Analysis of agricultural science. Univ. Egypt. 41: 551-566.

Radha, G. and Uma. M. 2015. Effect of gamma irradiation on germination and seedling parameters of Finger millet (Eleusine coracana L.). Int. Conf. on Bio Resource and Stress Management. 2: 20-25.

Radhakhrishna, S., B. Ramanicam, S. Rao. and Madhav, S. 1983. Efficacy of certain insecticides chemicals on Cajanus cajan seeds in storage. Pesticides. 17: 1920.

Rajarajeshwari, 2011. Studies on the effect of seed UV irradiation on growth, seed yield, quality and storability of chickpea genotypes. M.Sc. (Agri) Thesis, Univ. Agric Sci, Raichur.

Ravikumar, G. H., G. N. Kulkarni, B. S. Vyakaranahal and Shashidhara, S. D. 1987. Effect of fungicides and insecticides on storability of soybean genotypes. Plant Pathol. Newslett. 5: 11.

Richard, E., and Patrick, E. 2014. Sterilization of grains using ionizing radiation: The case in Ghana. European Sci. J. 10(6): 234-246.

Salter, L. and Hewitt, C. N. 1992. Ozone hydrocarbon interactions in plants. Phytochemistry. 31(4): 4045- 4050.

Savitri, H., R. M. Sugunkar and Muralimohan R. B. 1998. Effect of seed treatment with fungicides and insecticides on seed born fungi, storage insect pests, seed viability and seedling vigour of sorghum. Seed Res. 22 (2): 146- 155.

Selveraju, P. 2001. Investigations an seed dormancy and senescence in rice. Ph.D. Thesis, Tamil Nadu Agric. Univ, Coimbatore (India).

Shakoor, A., M. A. Haq. and Sadiq M. 1978. Induced genetic variability in $\mathrm{M} 2$ and evaluation of promising mutant lines in 
M4 generation of mung bean. Pakistan J. Agric Sci. 15(1-2): 1-6.

Simpson, G. M. and Naylor, J. M. 1962. Dormancy studies in seeds of Avena fatua. A relationship between maltase, amylases and gibberellins. Canadian J. Bot. 40: 1659-1673.

Sindhan, G. S., R. D. Parashar. and Indra, H. 1996. Effects of chemical seed treatments on incidence of flag smut and bio chemical constituents of wheat plant. Indian J. Mycol. 26: 60-63.

Sparrow, A.H. and Vans, 1961. Types of ionizing radiation and their cytogenetic effects. Symposium on Mutation and Plant Breeding, Cornell University, Ithaca, 28 November-2 December 1960, National Academy of Sciences Council Publication. Washington DC. 891: 55119.

Stoeva, N. and Z. Bineva, 2001. Physiological response of beans (Phaseolus vulgaris L.) to gamma-radiation contamination $\mathrm{I}$. Growth, photosynthesis rate and contents of plastid pigments. J. Env. Prot. Eco. 2: 299-303.

Stoeva, N., Z. Zlatev. and Bineva, Z. 2001. Physiological response of beans (Phaseolus vulgaris L.) to gammaradiation contamination, II. Waterexchange, respiration and peroxidase activity. J. Env. Prot. Eco., 2: 304-308.

Sundararaj, N., S. Nagaraju, M. N. Venkata Ramu. and Jagannath, M. R. 1972.
Designand analysis of experiments. Uni. of Agril. Sci., Bangalore. 148-155.

Sundaresh, H. N., K. J. Ranganathan, A. Janaradhan. and Vishwanatha, S.R. 1987. Chemical seed treatment against seed borne fungi in soybean. Curr. Res., 16: 110-111.

Tamiru, A., T. Bayih. and Chimdessa, M. 2016. Synergistic bioefficacy of botanical insecticides against Zabrotes subfasciatus (Coleoptera: bruchidae) a major storage pest of common bean. J. Fertilizer. Pesticides. 7(2): 817-824.

Taylor, A. G., P. S. Allen, M. A. Bennet, K. J. Bradford, J. S. Burris and Mishra, M. K. 1998. Seed enhancement. Seed Sci. Res. 8: 245-256.

Uma, M. S. and Salimath, P. M. 2001. Effect of ionizing radiations on germination and emergence of cowpea seeds. Karnataka J. Agric. Sci. 14(4): 1063-1064.

Veeresh, L. C., H. Shivashankar, Shailaga. and Hittalamani, S. 1995. Effect of seed irradiation on some plant characteristics winged bean. Mysore J. Agric. Sci. 29: 14.

Woodstock, L. W. and Justice, O. L. 1967. Radiation-induced changes in respiration of corn wheat, sorghum and radish seeds during initial stages of germination in relation to subsequent seedling growth. Radiation Botany. 7: 129-136.

Xiuzher, L. 1994. Effect of irradiation on protein content of wheat crop. J. Nucl. Agril.. Sci. China. 15, 53-55.

\section{How to cite this article:}

Pranesh, S.R. Doddagoudar, S.N. Vasudevan, N.M. Shakunthala and Aswathanarayana, D.S. 2019. Influence of Gamma Irradiation and Seed Treatment Chemicals on Seed Longevity of Bengal Gram (Cicer arietinum L.) and Black Gram (Vigna mungo L.). Int.J.Curr.Microbiol.App.Sci. 8(01): 2866-2881. doi: https://doi.org/10.20546/ijcmas.2019.812.334 